\title{
SISTEM INFORMASI PENJUALAN BARANG COMPRESSOR BERBASIS WEB ONLINE PADA PT.MULTI JUARA
}

\author{
Giandari Maulani ${ }^{1}$ \\ Abdul Rohim Kusuma Heri ${ }^{2}$ \\ Kartika Chandra Buana Sejati ${ }^{3}$ \\ giandari@raharja.info, abdulrohim@raharja.info,chandrabuana@ raharja.info
}

\begin{abstract}
ABSTRAK
Pada saat ini sistem informasi penjualan barang online melalui internet sedang berkembang pesat. Oleh sebab itu banyak perusahaan yang memanfaatkan teknologi yang berbasis website sebagai suatu strategi perusahaan dalam menawarkan barang mereka kepada seluruh customer tanpa harus dibatasi oleh ruang dan waktu. Mulai dari perusahaan besar hingga usaha kecil dan menengah telah menjadikan sistem penjualan secara online sebagai sarana promosi yang murah dan terjangkau. Barang yang ditawarkan oleh tiap situs-situs penjualan online sangat beragam dan juga diminati oleh masyarakat, peluang inilah yang dimanfaatkan oleh PT.Multi Juara untuk melebarkan sayap bisnisnya melalui produk unggulannya. PT.Multi Juara merupakan perusahaan yang bergerak dalam bidang penjualan barang Compressor. Penjualan barang ini dikhususkan kepada customer-customer yang membutuhkan Compressor sebagai alat pendukung pekerjaannya. Untuk meningkatkan angka penjualannya,PT.Multi Juara merumuskan sistem penjualan barang Compressor secara online melalui internet. Penjualan barang di dunia maya ternyata sangat efektif dan relevan untuk sekarang ini,sehingga terciptalah website yang berbasis online untuk penjualan barang Compressor sebagai pemenuhan kebutuhan penjualan barang yang mengikuti perkembangan zaman sekaligus meningkatkan omzet penjualan barang Compressor milik perusahaan PT.Multi Juara.
\end{abstract}

Kata kunci: Website berbasis Online, Penjualan Barang Compressor.

\section{ABSTRACT}

At this time the online sale of goods information system via the internet is growing by leaps and bounds. Therefore, many companies are utilizing technology based website as a corporate strategy in offering them to all customer items without having to be limited by time and space. Ranging from large corporations to small and medium enterprises have made an online sales system as a means of promotion of cheap and affordable. Goods offered by each online sales sites are very diverse and well sought after by the public, this opportunity exploited by PT. Multi Juara to widen its business through superior product wing. PT. Multi Juara is a company engaged in the sale of Compressor. The sale of these goods is devoted to the customer-the customer who needs a Compressor as a means of supporting his work. To increase the number of sales, PT. Multi Juara formulate goods sales system Compressor online over the internet. Sales of goods in cyberspace turned out to be very effective and relevant for today's online website, resulting in the sale of Compressor as a fulfillment of sales items that keep track of time while enhancing the turnover of goods of the company's Compressor PT. Multi Juara.

Keywords: Online Website, Sale of Compressor. 


\section{PENDAHULUAN}

Dunia teknologi informasi dari waktu ke waktu terus menerus mengalami perkembangan dan peningkatan yang signifikan. Hal tersebut didukung dengan berkembangnya teknologi yang semakin maju dan memadai. Sehingga informasi dapat diakses secara cepat, tepat, terkini, serta akurat. Selain berdasarkan pada hal tersebut, penyajian suatu informasi juga perlu mendapatkan perhatian serius untuk menarik customer. Pada saat ini sistem penjualan barang melalui internet sedang berkembang pesat. Banyak perusahaan yang memanfaatkan teknologi yang berbasis web sebagai suatu strategi perusahaan dalam menawarkan barang mereka kepada seluruh customer tanpa harus dibatasi oleh ruang dan waktu. Mulai dari perusahaan besar hingga usaha kecil dan menengah telah menjadikan sistem Penjualan secara online sebagai sarana promosi yang murah dan terjangkau. Barang yang ditawarkan oleh tiap situs-situs penjualan online sangat beragam, seperti kita ketahui salah satu kekurangan dari sistem penjualan online adalah customer tidak dapat melihat, meraba, dan merasakan secara langsung barang yang ditawarkan secara online. Akan tetapi barang jenis compressor memiliki ukuran dan berat atau materi yang dapat dideskripsikan secara jelas melalui media internet sehingga memudahkan customer untuk mengidentifikasi barang yang ditawarkan secara online.

PT Multi Juara merupakan perusahaan yang bergerak dalam bidang penjualan barang kepada pelanggan. Proses bisnis penjualan barang ke seluruh perusahaan yang ingin melakukan pemesanan suatu barang. Penggunaan sistem manual tidak sepenuhnya merugikan perusahaan, bahkan biasanya sistem manual bisa dikatakan kinerjanya lebih cepat bila dibandingkan dengan sistem yang sudah terkomputerisasi. Namun dari hasil pengamatan terhadap perusahaan yang dijadikan objek dalam analisa ini, terdapat banyak hambatan pada proses bisnis sistem berjalan yang digunakan. Oleh karena itu dasar pertimbangan bahwa penggunaan sistem manual yang digunakan banyak sekali hambatan-hambatannya, maka untuk mengatasi masalah tersebut, dilakukanlah penelitian untuk membuat suatu sistem informasi berupa website penjualan berbasis online terutama untuk barang yang berupa Compressor yang bertujuan untuk dapat meningkatkan kinerja kerja dan omzet penjualan pada PT.Multi Juara.

\section{KAJIAN LITERATUR}

Menurut Norman L.Enger dalam buku Tata Sutabri (2012:7) Sistem dapat terdiri dari atas kegiatan-kegiatan yang berhubungan guna mencapai tujuan-tujuan perusahaan seperti pengen- dalian inventaris atau penjadwalan produksi[8]. Menurut Tata Sutabri (2012:20) Model umum sebuah sistem adalah Input, Proses dan Output. Hal ini merupakan konsep sebuah sistem yang sangat sederhana sebab sebuah sistem dapat mempunyai beberapa masukan dan keluaran. Selain itu, sebuah sistem memiliki karakteristik atau sifatsifat tertentu, yang mencirikan bahwa hal tersebut bisa dikatakan sebagai suatu sistem[8], Sedangkan Informasi menurut Raymond McLeod dalam buku Yakub (2012:8) adalah Sekumpulan fakta (data) yang diorganisasikan data yang diolah menjadi bentuk yang lebih berguna bagi penerimanya[9]. Menurut Sutarman (2012:14) Nilai dari informasi ditentukan oleh beberapa hal yaitu: Untuk memperoleh pemahaman dan manfaat, Untuk mendapatkan pengalaman, Pembelajaran yang terakumulasi sehingga dapat diaplikasikan dalam pemecahan masalah atau proses bisnis tertentu, Untuk mengekstrak implikasi kritis dan merefleksikan pengalaman masa lampau yang menyediakan pengetahuan yang terorganisasi dengan nilai yang tinggi. Nilai ini bisa menghindari seseorang manajer dari membuat kesalahan yang sama yang dilakukan oleh manajer lain. Suatu informasi dikatakan bernilai bila manfaatnya lebih efektif dibandingkan dengan biaya mendapatkannya. Sebagian besar informasi dapat ditaksir keuntungan nya dengan suatu nilai uang, tetapi dapat 
ditaksir nilai efektivitasnya[7]. Dari pembahasan definisi diatas, maka jika digabung definisi Sistem dan Informasi akan menjadi definisi Sistem Informasi seperti yang dikemukakan oleh Tata Sutabri (2012:38) bahwa " Sistem informasi adalah suatu sistem didalam suatu organisasi yang mempertemukan kebutuhan pengolahan transaksi harian yang mendukung fungsi operasi organisasi yang bersifat manajerial dengan kegiatan strategi dari suatu organisasi untuk dapat menyediakan laporan-laporan yang diperlukan oleh pihak luar tertentu" [8] dan Menurut Sutarman (2012:14-15) Sistem informasi terdiri dari komponenkomponen yang disebut dengan istilah blok bangunan (building block), yang terdiri dari blok masukan, blok model, blok keluaran, blok teknologi, blok basis data, dan blok kendali. Sebagai suatu sistem, keenam blok tersebut saling berinteraksi satu sama lain membentuk satu kesatuan untuk mencapai tujuan atau sasaran tertentu[7]. Sedangkan untuk definisi Penjualan menurut Puspitawati dan Anggadini (2011:165) dikemukakan bahwa penjualan merupakan "aktivitas yang memperjualbelikan barang dan jasa kepada konsumen"[4]. Sedangkan menurut Rama dan Jones (2011:22) Penjualan (siklus pendapatan) mengacu pada "proses menyediakan barang dan jasa untuk para pelanggan"[5]. Dari pengertian di atas dapat diambil kesimpulan bahwa penjualan adalah suatu transaksi dalam perusahaan yang menyediakan dan memperjualbelikan barang dan jasa kepada pelanggan dimana proses transaksi tersebut bertujuan untuk mendapatkan keuntungan atau laba bagi perusahaan. Menurut Kustiyahningsih (2011:113) "Web adalah layanan yang di dapat yang di dapat oleh pemakai komputer yang terhubung ke internet"[2]. Menurut Murya (2012:3) “ Web (World Wide Web) adalah Suatu layanan sajian informasi yang menggunakan konsep hyperlink (tautan), media memudahkan surfer (sebutan para pemakai komputer yang melakukan browsing atau penelusuran informasi melalui internet)"[3]. Menurut Sidik dan Husni (2012:1) "Web adalah ruang informasi dalam internet, dengan menggunakan teknologi hyperteks, pemakai dituntun untuk menemukan informasi dengan mengikuti link yang disediakan dalam dokumen web yang dtampilkan dalam browser web"[6]. Dari pendapat di atas dapat disimpulkan bahwa web merupakan layanan yang dapat oleh pemakai komputer terhubung ke internet, baik berupa teks, gambar, suara maupun video yang interaktif dan mempunyai kelebihan untuk menghubungkan (link) satu dokumen dengan dokumen lainnya (hypertext) yang dapat diakses melalui sebuah browser.

Adapun Fungsi dari Website Menurut Hidayat (2010:4) terbagi atas: Personal Website; Website yang berisi informasi pribadi seseorang, Commercial Website; Website yang dimiliki oleh sebuah perusahaan yang bersifat bisnis, Government Website; Website yang dimiliki oleh instansi pemerintah, pendidikan yang bertujuan memberikan pelayanan kepada pengguna, Non-Profit Organization Website yang dimiliki oleh organisasi yang bersifat non-profit atau tidak bersifat bisnis [1]. Menurut Murya (2012:6) website mempunyai fungsi yang bermacam-macam, tergantung dari tujuan dan jenis website yang dibangun tetapi secara garis besar dapat berfungsi sebagai: Media Promosi; Sebagai media promosi dapat dibedakan menjadi media promosi utama, misalnya website yang berfungsi sebagai search engine atau toko Online, atau sebagai penunjang promosi utama, namun website dapat berisi informasi yang lebih lengkap dari pada media promosi offline seperti Koran atau majalah. Sebagai Media Pemasaran; Pada toko Online atau Sistem afiliasi, website merupakan media pemasaran yang cukup baik, karena dibandingkan dengan toko sebagaimana di dunia nyata, untuk membangun toko online diperlukan modal yang relatif lebih kecil, dan dapat beroperasi 24 jam walaupun pemilik website tersebut sedang istirahat atau sedang tidak ditempat, serta dapat diakses darimana saja. Sebagai Media Informasi; Website portal dan radio atau TV online menyediakan informasi yang bersifat global karena dapat diakses dari mana 
saja selama dapat terhubung ke internet, sehingga dapat menjangkau lebih luas daripada media informasi konvensional seperti koran, majalah, radio atau telivisi yang bersifat lokal. Sebagai Media pendidikan; Ada beberapa komunitas yang membangun website khusus berisi informasi atau artikel yang sarat dengan informasi ilmiah misalnya Wikipedia. Dan sebagai Media komunikasi; Sekarang banyak terdapat website yang dibangun khusus untuk berkomunikasi seperti forum yang dapat memberikan fasilitas bagi para anggotanya untuk saling berbagi informasi atau membantu pemecahan masalah tertentu[3]. Menurut Kustiyahningsih (2011:8), "Web browser adalah software yang digunakan untuk menampilkan informasi dari server web. Software ini kini telah dikembangkan dengan menggunakan user interface grafis, sehingga pemakai dapat dengan melakukan 'Point and Click' untuk pindah antar dokumen [2]. Dapat dikatakan saat ini hanya ada empat web browser GUI yang populer: Internet Explorer, Netscape Navigato, Opera dan Mozilla. Keempat browser ini bersaing untuk merebut pemakainya, dengan berusaha untuk mendekati standar spesifikasi dokumen HTML yang direkomdasikan oleh W3C (World Wide Web Consorlium)

Berdasarkan pengertian diatas Web browser merupakan aplikasi perangkat lunak yang berfungsi sebagai interface untuk menjelajahi, mengambil maupun menyajikan berbagai macam sumber informasi berupa halaman web pada World Wide Web (WWW). Awalnya Web Browser hanya berorientasi pada teks dan belum dapat menampilkan gambar. Namun seiring berkembangnya jaman web browser tidak lagi hanya menampilkan text dan gambar tetapi juga file multimedia seperti video dan suara. Browser juga dapat mengirim dan menerima e-mail, mengelola bahasa Hyper Text Markup Language (HTML) sebagai input dan menjadikan halaman web sebagai hasil output yang informatif.

\section{METODE PENELITIAN}

Metode penelitian merupakan tahapan-tahapan yang dilakukan dalam melakukan penelitian jurnal ini. Tahapantahapan yang dilakukan dalam penelitian ini dapat dilihat pada gambar 1 dibawah ini:

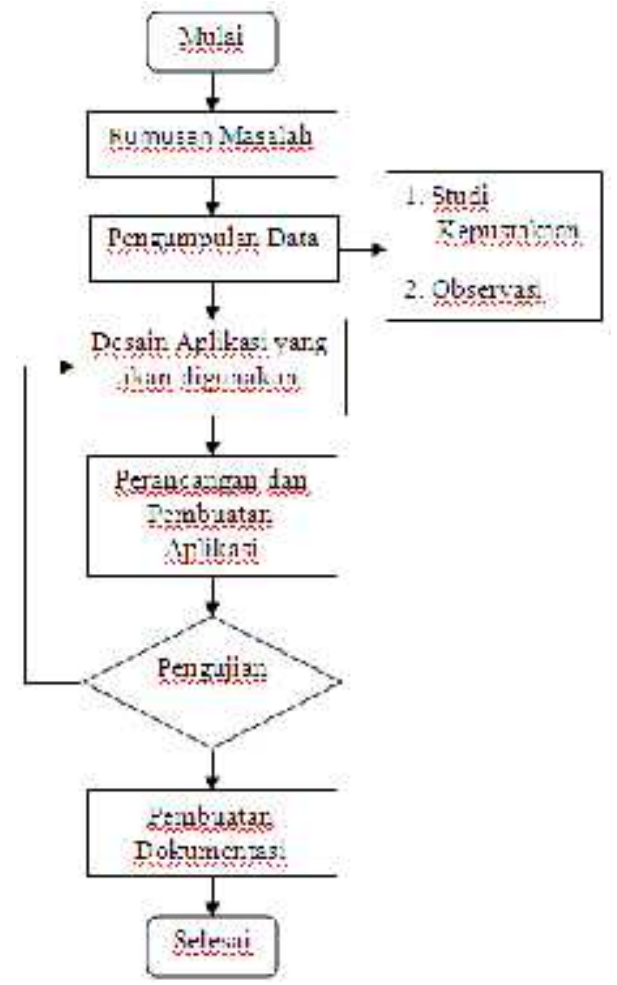

Gambar 1 Flowchart Metode Penelitian

Berikut ini merupakan penjelasan dari gambar 1 desain penelitian yang digunakan dalam metode penelitian ini:

1. Perumusan masalah merupakan dasar pemikiran dalam penelitian ini,dalam penelitian permasalahan yang akan diuraikan dan dianalisis mengenai proses penjualan barang compressor yang dilakukan oleh PT.Multi Juara.

2. Dalam pengumpulan data penelitian terdapat dua tahap metode yang dipakai,yaitu: studi pustaka dan observasi.

a. Studi pustaka: dalam metode ini peneliti melakukan pengumpulan beberapa literatur yang mendukung dalam penulisan penelitian ini, diantaranya mengumpulkan buku- 
buku, jurnal dan beberapa sumber ilmiah lainnya, seperti situs internet ataupun artikel dalam bentuk teks dokumen yang berhubungan dengan penelitian ini. sebagai contoh beberapa sumber yang membahas tentang penjualan barang.

b. Metode observasi: peneliti mengadakan pengamatan secara langsung di lokasi penelitian yaitu PT.Multi Juara untuk mengambil data-data yang sekiranya dapat dijadikan data tambahan dalam penelitian ini.

3. Untuk membangun infrastruktur dalam pembuatan website online penjualan barang Compressor pada PT.Multi Juara ini langkah berikutnya adalah menetukan kebutuhan akan perangkat keras (hardware) dan perangkat lunak (software) yang akan digunakan dalam penelitian ini. Dalam pemilihan hardware telah disesuaikan dengan kondisi di lapangan, sehingga tidak ada kendala baik hardware maupun software yang akan dipakai.

4. Tahap berikutnya adalah perancangan dan pembuatan aplikasi, dalam hal ini adalah pembuatan aplikasi Website Online yang didalamnya berisi hal-hal yang berkaitan dengan penjualan barang, khususnya barang Compressor untuk perusahaan PT.Multi Juara.

5. Tahap pengujian dimaksud untuk menguji seberapa handal website online yang telah dibuat berdasarkan kepada metode pengujian blackbox system.

6. Pada tahap ini peneliti membuat dokumentasi-dokumentasi yang di perlukan, agar setiap tahapnya ter-record dengan baik dan dapat dijadikan acuan pada tahap selanjutnya.

\section{HASIL DAN PEMBAHASAN}

Hasil identifikasi kebutuhan yang diperoleh melalui wawancara serta observasi; didapatkan spesifikasi pengguna dan fungsi yang diperoleh masing-masing pengguna. Tingkatan pengguna ditujukan untuk mengamankan basis data dari pengguna yang tidak berhak serta membatasi dengan hak akses user. Untuk mendapatkan hak akses sesuai dengan tingkatan pengguna melalui Login pada website online penjualan barang Compressor ini maka digunakan Username dan Password yang diberikan kepada pengguna (User).

Berikut dibawah ini merupakan tampilan Login website online penjualan barang Compressor untuk para pemegang hak akses diperusahaan PT.Multi Juara yang didalam Loginnya berisi Username dan Password:

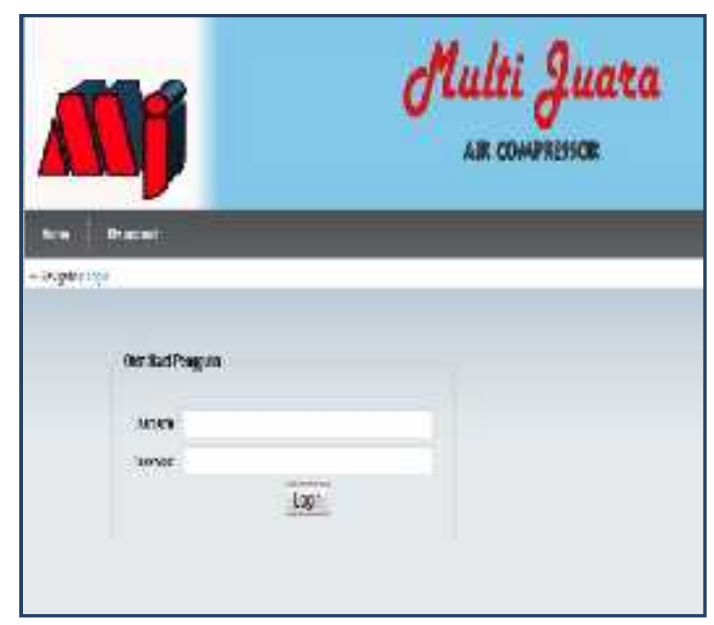

Gambar 2 Tampilan Login

Gambar 2 diatas merupakan tampilan Login yang dapat digunakan oleh user pemegang hak akses untuk masuk kedalam web online penjualan barang Compressor.

Berikutnya adalah tampilan Home:

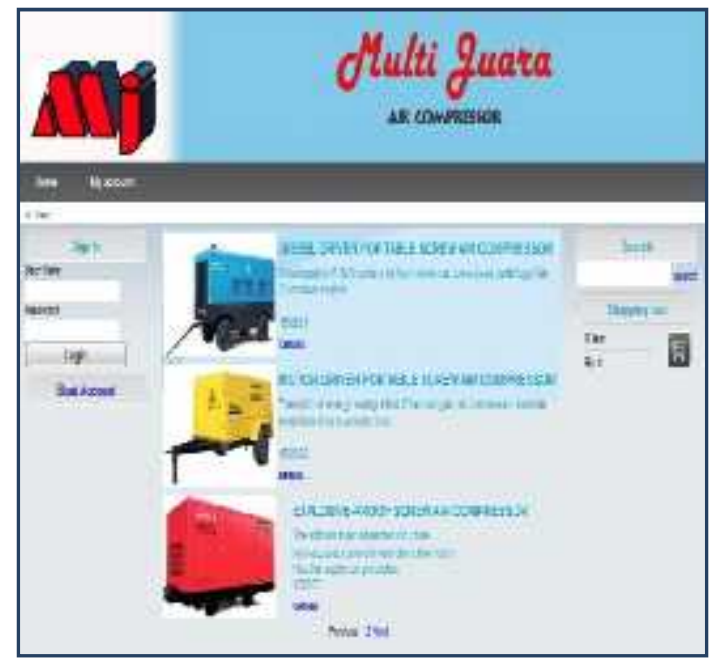

Gambar 3 Tampilan Home

Gambar 3 diatas merupakan tampilan Home yang merupakan tampilan muka pada web online penjualan barang Compressor pada PT.Multi Juara yang berisi informasi- 
informasi yang berkaitan dengan barangbarang Compressor.

Sedangkan gambar 4 dibawah ini adalah tampilan menu kategori barang Compressor:

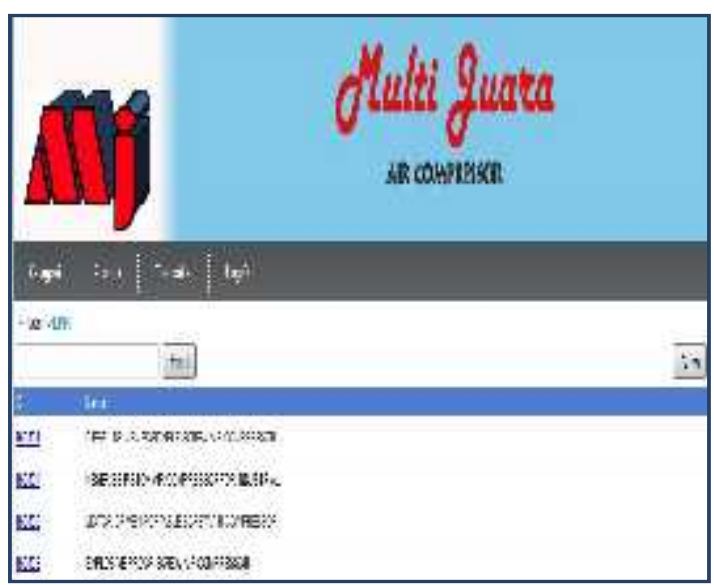

Gambar 4 Tampilan menu Kategori

Gambar 4 menampilkan menu kategori yang berisi keterangan kelompok kode dan jenis barang Compressor. Dari sini customer dapat melihat kategori Compressor yang sesuai dengan kebutuhannya.

Dan untuk memilih Produk yang diinginkan, customer dapat melihat disini:

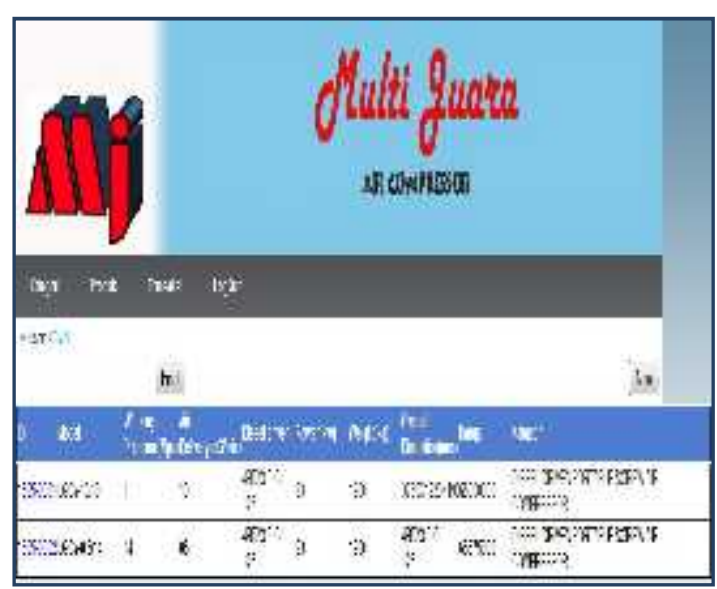

\section{Gambar 5 Tampilan menu Produk}

Gambar 5 diatas menampilkan menu produk barang Compressor secara lengkap sesuai dengan spesifikasinya masing-masing. Customer diberikan informasi tentang produk dan diberikan kemudahan memilih produk yang sesuai agar tidak salah didalam pemilihan produk barang Compressornya.
Yang berikut ini adalah tampilan menu transaksinya:

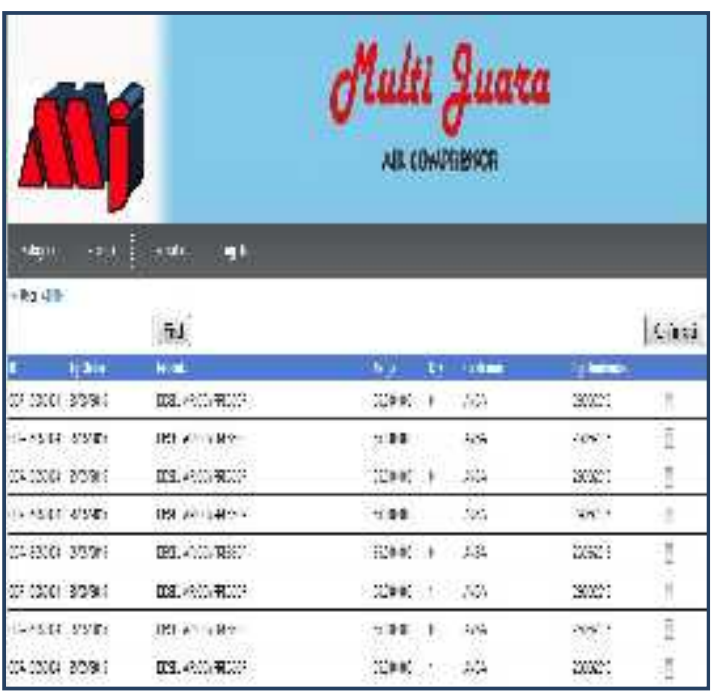

Gambar 6 Tampilan menu transaksi

Gambar 6 merupakan tampilan menu transaksi yang berguna untuk menampilkan informasi lalu lintas transaksi yang dilakukan selama periode tertentu.

Untuk melihat detail barang customer juga disediakan laporannya didalam website seperti dibawah ini:

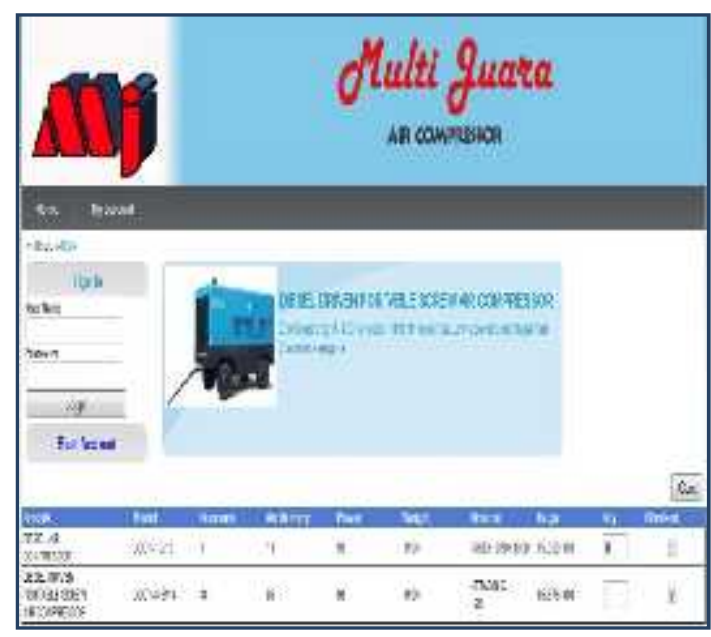

Gambar 7 Menu detail barang Customer

jumlah customernya yang aktif memesan barang, sekaligus juga dapat memberikan input positif bagi perusahaan; dalam hal ini PT.Multi Juara untuk menjaga hubungan baik dengan para customernya. 


\section{KESIMPULAN}

Pada saat ini sistem penjualan
barang melalui internet sedang berkembang pesat. Banyak perusahaan yang memanfaatkan teknologi yang berbasis web sebagai suatu strategi perusahaan dalam menawarkan barang mereka kepada seluruh customer tanpa harus dibatasi oleh ruang dan waktu. Peluang inilah yang dimanfaatkan oleh PT.Multi Juara untuk melebarkan sayap bisnisnya dan sebagai upaya untuk meningkatkan omzet penjualannya. PT.Multi Juara merupakan nama sebuah perusahaan yang bergerak dalam bidang penjualan barang-barang Compressor. Perusahaan ini menjual produknya khusus kepada para customer yang membutuhkan Compressor sebagai alat pendukung pekerjaannya. Penjualan barang melalui website yang berbasis online seperti barang jenis Compressor ini ternyata cocok dipromosikan dengan media online ini karena Compressor memiliki ukuran dan berat atau materi yang dapat dideskripsikan secara jelas melalui media online sehingga memudahkan customer untuk mengidentifikasikan barang yang ditawarkan dan memilihnya sesuai dengan kebutuhan.

\section{DAFTAR PUSTAKA}

1) Hidayat,Rahmat.'Tips \& Cara Praktis Membangun Website Gratis". Jakarta: PT.Elex Media Komputindo,2010.

2) Kustiyahningsih,Yeni. "HTML dan Konsep Dasar Web". Jakarta: Graha Ilmu,2011.

3) Murya,Yosef. "PHP Menyelesaikan Website 30 Juta". Yogyakarta: Jasakom,2012.

4) Puspitawati. Anggadini. "Penjualan dan strategi Penjualan". Jakarta: Bumi Aksara,2011.

5) Rama. Jones. "Pengaruh Keputusan Pelanggan Terhadap Penjualan". Jakarta: Karisma Publishing Group, 2011.
6) Sidik,Betha. Pohan,Husni. "Pemogra- man Web dengan HTML". Bandung: Informatika Bandung,2012.

7) Sutarman. "Pengantar Teknologi Informasi”.Yogyakarta:Bumi Aksara, 2012.

8) Sutabri,Tata. "Analisa Sistem Infor- masi". Yogyakarta: Andi Offset, 2012.

9) Yakub. "Pengantar Sistem Informasi". Yogyakarta: Graha Ilmu, 2012. 